Southern Illinois University Edwardsville SPARK

SIUE Faculty Research, Scholarship, and Creative Activity

6-28-2016

\title{
The Second Wilde Revival: Current Trends in Oscar Wilde Scholarship
}

Helena Gurfinkel Dr.

Southern Illinois University Edwardsville, hgurfin@siue.edu

Follow this and additional works at: http://spark.siue.edu/siue_fac

Part of the Literature in English, British Isles Commons

\section{Recommended Citation}

Kritikon Litterarum. Volume 43, Issue 1-2, Pages 143-166, ISSN (Online) 1865-7249, ISSN (Print) 0340-9767, DOI: 10.1515/ kl-2016-0028, June 2016

This Article is brought to you for free and open access by SPARK. It has been accepted for inclusion in SIUE Faculty Research, Scholarship, and Creative Activity by an authorized administrator of SPARK. For more information, please contact gpark@siue.edu. 


\section{Cover Page Footnote}

This article was originally published in:

Kritikon Litterarum. Volume 43, Issue 1-2, Pages 143-166, ISSN (Online) 1865-7249, ISSN (Print) 0340-9767, DOI: 10.1515/kl-2016-0028, June 2016 


\section{Review Essay}

\section{The Second Wilde Revival: Current Trends in Oscar Wilde Scholarship}

Bristow, Joseph (ed.): Wilde Discoveries: Traditions, Histories, Archives. Toronto: U of Toronto Press, 2013. 390 pp.

Goldstone, Andrew: Fictions of Autonomy: Modernism from Wilde to de Man. Oxford, New York: Oxford UP, 2013. 204 pp.

Moyle, Franny: Constance: The Tragic and Scandalous Life of Mrs. Oscar Wilde. New York, London: Pegasus Books, 2011, 2012. 374 pp.

Powell, Kerry; Raby, Peter (eds.): Oscar Wilde in Context. New York: Cambridge UP, 2014. $402 \mathrm{pp}$.

Ross, Iain: Oscar Wilde and Ancient Greece. New York: Cambridge UP, 2011, 2012, 2013. 274 pp.

Salamensky, S. I.: The Modern Art of Influence and the Spectacle of Oscar Wilde. New York: Palgrave Macmillan, 2011. 210 pp.

Walshe, Éibhear: Oscar's Shadow: Wilde, Homosexuality and Modern Ireland. Cork: Cork UP, 2011. 149 pp.

Reviewed by: Helena Gurfinkel (Department of English Language and Literature, Southern Illinois University Edwardsville, U. S. A.)

DOI 10.1515/kl-2016-0028

\section{The Two Revivals: An Overview}

Nearly two decades have passed since the last Wilde revival. In the 1990s, when queer theory and LGBT studies were still relatively new phenomena in the academy, and when the struggle for the visibility of LGBTQ people in visual media was still in its infancy, Oscar Wilde became a perfect conduit for both. Queer theorists deployed Wilde's penchant for redefining lying as creativity and 
"immoral" behavior as a way to multiply and redefine selves. Wilde's protean non-identity was post-structuralist avant la lettre, and, given Wilde's affinity with Nietzsche, a precursor to deconstruction, at the time foundational to queer theory. Simultaneously, Foucauldian queer theory positioned Wilde and his work at the explosive intersection of power, pleasure, and surveillance. More historically and materially-oriented critics considered the social and economic implications of Wilde's celebrity and focused on Wilde in their analyses of historical developments of Victorian genders, sexualities, celebrities, and the literary marketplace.

A brilliant constellation of queer analyses of Wilde did not just originate in the 1990s; in many ways, it epitomized the academic 1990s, with their triumph of Foucault, the still considerable (but waning) influence of deconstruction, and the rising tide of materialist approaches. The work of Eve Kosofsky Sedgwick, Jonathan Dollimore, Joseph Bristow, Christopher Craft, Ed Cohen, Alan Sinfield, Richard Dellamora, and Regenia Gagnier had laid the foundation of Wilde scholarship and still serves as an inspiration for the new wave of Wilde criticism. ${ }^{1}$

Such is the inimitable paradox of Oscar Wilde that, while in the academy, Wilde made a case for a non-existent identity, for the public at large, in the late 1990s, he served as an anchor for a very public and legible gay male selfhood. Broadway plays by the likes of Moisés Kaufman and films such as Wilde and $A$ Man of No Importance focused on his persecution and trials and made the story of Wilde the gay man human, contemporary, and a political battle cry.

Whether academic or popular, deconstructing or hanging on to identity, the 1990s explorations of Wilde's life and work honed in almost exclusively on his sexuality. I will argue below, however, that the recent Wilde revival, a veritable wave of high-quality scholarship landing now on our shores, is going in the opposite direction. Sexuality is de-centered in most of the edited collections and monographs that I will discuss here. The focus on queerness as identitarian aporia, or on gay martyrdom as a clearly articulated political identity, is replaced

1 See Eve Kosofsky Segwick's “Tales of the Avunculate: The Importance of Being Earnest" in Tendencies (1993); Jonathan Dollimore's Sexual Dissidence: Augustine to Wilde, Freud to Foucault (1991); Joseph Bristow's Effeminate England: Homoerotic Writing after 1885 (1995); Christopher Craft's Another Kind of Love: Male Homosocial Desire in English Discourse, 1850-1920 (1995); Ed Cohen's Talk on the Wilde Side: Towards a Genealogy of a Discourse on Male Sexualities (1992); Richard Dellamora's Masculine Desire: The Sexual Politics of Victorian Aestheticism (1990); Alan Sinfield's The Wilde Century: Effeminacy, Oscar Wilde, and the Queer Moment (1994); and, the earliest of them all, Regenia Gagnier's Idylls of the Marketplace: Oscar Wilde and the Victorian Public (1986). 
by a different host of concerns, some of which have less to do with either side of identity politics than others.

The current Wilde revival draws attention, instead, to the growing acceptance of Wilde's status as an proto-, or early, modernist, rather than a Victorian; various manifestations of material culture; Wilde's philosophy and scholarship, especially on Ancient Greece; Wilde's national and ethnic (rather than sexual) Otherness; and his religious beliefs. Finally, supplanting the virtually exclusive 1990s focus on Wilde's homoeroticism and homosociality, comes greater interest in Wilde's relationship with women. While the complete departure from discussions of sexuality is not entirely welcome (is Wilde the martyr no longer needed?), a greater focus on women in his circle certainly is.

For example, his wife, Constance (Lloyd) Wilde, formerly merely a bit player in the tragedy taking place in Tite Street, the Old Bailey, the Clapham Junction, the Reading Gaol, and Paris, is beginning to get well-deserved attention as a thinker and activist in her own right. The influence of his mother, Lady Jane Wilde, obviously stretches beyond the well-worn, pseudo-Freudian discussion of dressing her infant son in "girl's" clothes. She has much to do with Wilde the scholar and the Irishman. In what follows, I will discuss a number of scholarly monographs and edited collections, as well as one biography intended for the general public (the list is by no means exhaustive), that have been published in the last four years and reflect changes in Wilde scholarship. In general, they tend to focus, with a considerable degree of success and innovation, on the six aspects of Wilde work listed above, at times singling out one or two, while, at other times, endeavoring to cover all.

\section{The Second Wave's Foundational Texts}

Two recent collections edited by prominent Wilde scholars include essays that illuminate, and sometimes start, important trends of the current Wilde scholarship revival. Wilde Discoveries: Traditions, Histories, Archives, edited by Joseph Bristow, originates in the recent "Wilde Archives" summer seminar, hosted by the William Andrews Clark Memorial Library at the University of California, Los Angeles. The Clark Library, also the co-publisher of this volume, boasts the world's largest Wilde archive, and the work presented in this meticulously edited and researched book stems from the painstaking archival work of the participants. The very origins of the volume in an archive suggest a sea change in Wilde scholarship from theory and (re)signification to materiality and historicity, as does its conventionally chronological organization. Indeed, a number of contributors focus on the material aspects of Wilde's creative output, while others take 
their research in such new directions as religious studies, translation studies, and textual criticism. Selected essays also explore the link between Wilde's writings and the women's movement and Romanticism.

The collection is divided into five sections. In the first section, "Romanticism, Nihilism, and Revivalism, 1874-1882," the authors put the younger Wilde in historical and intellectual contexts, thus signaling a move away from the poststructuralist, sexual identity-defying, play-of-the-signifier-oriented scholarship that characterized most of the 1990s Wilde research. Significantly, too, in keeping with the current critical turn, gender and sexuality are far from being this section's concern. In fact, whenever gender comes into play in Bristow's collection, it is usually in relation to women and Wilde's feminism.

In the opening essay of the collection, Chris Foss argues for a powerful link between Wilde and the Romantic poets that he admired. Foss contends that the young Wilde was not a "Romantic Egoist," or simply an imitator of his poetic role models, but

...an earnest advocate for a renaissance of art that he regarded as a properly Romantic movement. At the same time, as a Romantic Ironist, he prefers to complicate rather than to complete questions concerning the relationship between art and life, beauty and truth, body, and soul, mind and feeling... (p. 61)

Like Foss, Elizabeth Carolyn Miller confirms Wilde's oppositional stance to Victorian realism, but she does so by linking Wilde to his contemporary political movements: (Russian) nihilism and anarchism. In "Reconsidering Wilde's Vera; or, The Nihilists," she writes that

...the overtly revolutionary theme of Vera highlights radical elements across Wilde's body of work, and that the play's attack on British imperialism, expressed circuitously through a representation of Russian imperialism, exemplifies aestheticism's broader tendency towards antirealist political aesthetics. This kind of antirealism is likewise apparent in the play's gender politics and its fascinating alignments of feminism, political terror, and democratic reform... (pp. 65-66)

Miller's innovation lies both in drawing more attention to the often neglected and ostensibly unsuccessful early play and in making a rare gesture towards politicizing the aesthetic movement and suggesting that its proto-modernist "antirealist" stance is more than art for art's sake and has specific social implications.

Miller's essay links nicely both to other feminist analyses in the volume and to the concluding essay of the first section, Gregory Castle's "Misrecognizing Wilde: Media and Performance on the American Tour of 1882." Known for his work in Irish Studies and postcolonial theory, Castle locates Wilde's performance on the U.S. tour in two contexts: modernism and Irish Revivalism. Castle writes, 
Wilde's self-consciousness of his own development, which I see crystallized during the 1882 tour, is a version of the aesthetic Bildung that subtends a wide variety of modernist projects. There is also an important Irish context...The use of the past in Wilde's cultural performance...corresponds on many important points with those of Irish revivalists. (p. 86)

Castle's contribution both dovetails with Miller's essay in emphasizing Wilde's opposition to British imperialism (thus contributing to a robust, and still developing, line of inquiry into the postcolonial Wilde) and launches an important conversation about Wilde the (Irish) modernist, continued, in this volume, by John-Paul Riquelme, and, in another context, by Andrew Goldstone's new book.

The second section of the book, "Journalism: Oscar Wilde and The Woman's World, 1887-1889," explores the material Wilde (this time in relation to print culture) and the feminist Wilde. In "The Aesthetic Character of Oscar Wilde's The Woman's World," Molly Youngkin enters into a conversation with Elizabeth Carolyn Miller and, through a close reading of Wilde's reviews and essays in The Woman's World, as well as through an analysis of "The Decay of Lying," suggests that Wilde indeed does take a strongly anti-realist stance. However, she cautions us against assuming that Wilde rejects realism wholesale. He advocates, instead, "the right realism" (p. 122) that "leaves the mystery of life intact" (p. 124), thus complicating, in a "true" Wildean fashion, his own newly-established position as a modernist. While, according to Wilde, nineteenth-century Russian novelists can get realism right, French naturalist and English "social-reform" novelists fail rather miserably at it.

Given Wilde's preference for aestheticism over realism, Youngkin argues, The Woman's World (the title of which, as we know, Wilde changed from The Lady's World upon taking over its editorship) served as the venue for celebrating and disseminating the work of women-aesthetes, and, despite Wilde's limitations as a feminist, has influenced "the progressive women's community today" (p. 139). Confirming Youngkin's view of the journal as an influential feminist publication, Loretta Clayton, in "Oscar Wilde, Aesthetic Dress, and the Modern Woman: On Why Sargent's Portrait of Ellen Terry Appeared in The Woman's World," reads the journal's illustrations closely and contends that "...Wilde set out to mould a specialised female reader: the aesthetic consumer who anticipated unconventional images of beauty and style and who spoke a new language of fashion aesthetic dress reform" (p. 143). John Sargent's engraving "Miss Ellen Terry as Lady Macbeth," which appeared in The Women's World in 1889, exemplifies precisely the sort of "decidedly modern view of women's beauty and glamour" (p. 159) that the journal sought to propagate. Though one wishes for a more extensive inquiry into the significance of Shakespeare's character for the cause of female empowerment, Clayton's essay certainly makes a strong claim for the journal's - and the engraving's - social and aesthetic import, as well as contri- 
butes to the new and burgeoning research on Wilde and the print culture of the fin de siècle.

The third section, "Faith, Belief, and Fiction: Oscar Wilde, 1889-1891," departs from materiality and, in an appropriately counter-intuitive fashion, frames what is widely considered Wilde's sexually and artistically most transgressive period as the period of heightened spiritual significance. In fairness, however, the essays' approach to religion is far from traditional. In "Sexual Gnosticism: The Procreative Code of 'The Portrait of Mr. W. H.',” James Campbell comes as closely as this collection ever does to positioning gay male sexuality at the center of the argument, but he approaches it in a manner quite different from that of the queer readings of the 1990s.

Through a careful reading of the story's publishing and writing history (which also gives its due to the study of the print culture), Campbell comes to the conclusion that “...Wilde presents in 'The Portrait of Mr. W. H.' a theory of masculine relationships that so closely parallels heterosexual procreation that it becomes impossible to determine with any precision which is the original and which is the analogue" (p. 175). By itself, this conclusion, as well as Campbell's claim that "Mr. W. H." speaks against “one great Truth about queerness" (p. 185), echoes what we have heard before, from Shakespeare and Shakespeareans on art as procreation, and from Judith Butler on drag. ${ }^{2}$ However, Campbell's analysis has an intriguing second part. The problematic of originality, truth, and imitation that permeates the story also calls to mind the problematic of faith and belief, which the story, according to the critic, simultaneously invites and disallows. Ultimately, Campbell argues, “The Uranian gnosis of 'The Portrait of Mr. W. H.' is a lie, but a lie by all means to be believed" (p. 185).

Likewise, belief is at the center of Rachel Ablow's "Reading and Re-Reading: Wilde, Newman, and the Fiction of Belief.” Ablow points out that Wilde's relationship to religion, and especially to the work of Cardinal Newman, has not been sufficiently explored. Like Campbell, she takes up "The Portrait of Mr. W. H." and examines the relationship between belief and desire; however, she does so by drawing an explicit comparison between Newman's An Essay in Aid of a Grammar of Assent (1870) and Wilde's story. Ablow argues that "[i]n both cases...the believer believes because he loves - and, as Wilde insists, when we love, we join ourselves to the beloved in a way that looks like nothing so much as what we do when we 'enter into' or read a fiction'” (p. 204). Ablow's reading enriches our understanding of Wilde's faith, and particularly of his relationship with Catholi-

2 I am referring, of course, to Judith Butler's Gender Trouble: Feminism and the Subversion of Identity (1990). 
cism, about which our thinking had hitherto been limited by the now somewhat tired notions of costume, theatricality, and performance.

A bit tired, as well, is the question whether or not, in the words of that other queer Mr. W. H., Auden, The Picture of Dorian Gray, is a moralistic "bore." But Neil Hultgren's answer in “Oscar Wilde's Poetic Justice in The Picture of Dorian Gray" is fresh and sophisticated. He notes that we understand Wilde's aversion to, and critique of, action (related, perhaps, also to his critique of the realist novel), to be one of the central tenets of his philosophy. Wilde's critique of action starts in his university notebooks and culminates in "The Critic as Artist." In The Picture of Dorian Gray, Hultgren suggests, the character of James Vane, who takes action against the protagonist, simultaneously invites sympathy as a workingclass character, whose life is destroyed by an insouciant and cruel upper-class dandy, and embodies a cheaply melodramatic, moralizing approach to fiction and life. According to the essay, James Vane's “melodrama” (p. 226) leads Wilde to the idea that "certain kinds of action in relation to literature - those that would lead to censorship or litigation - were certainly a misfire” (p. 226). Hultgren's analysis of James Vane and class links up nicely to Miller's politicization of Wilde's aesthetics, as well as to Andrew Goldstone's discussion of servants in Wilde's novels that I will consider below.

Morality is at stake in the last essay of Part Three, while the first essay of Part Four, "Translation, Performance, and the Stage: Oscar Wilde and The Stage," focuses on the notoriously immoral play Salomé. In his smartly titled essay, "Wilde's French," William Cohen considers the vicissitudes of translation, as well as Wilde's relationship to the French language and literature, illustrated most vividly by the aforementioned one-act tragedy written originally in French. Cohen claims that Wilde's French is not a national language but the cosmopolitan language of art that "reaches beyond nationality" (p. 234). To be sure, Wilde's use of French, like his Irishness, intimate Otherness (thus linking Cohen's essay to Castle's), but Cohen cautions us against attributing any national characteristic or affinities to Wilde, lest we become like "the hostile English press" that "never forgets his Irish origins" (p. 248). Instead, by demonstrating an allegiance to French, Wilde shows us that an artist holds no passport, and that "Shakespeare, too, is French" (p. 251).

Whereas, according to Cohen, the language of Salomé serves to liberate us from the narrow shackles of national identity, according to Lois Gugullu's "Fashioning the Modern Women's Sexual Turn from Salomé to Ulysses, 1892-1922," Wilde's work, and particularly Salomé, contribute to "women's sexual emancipation” (p. 261) by de-naturalizing female sexuality and making it a matter of style. Gugullu's essay is an exhilarating romp through turn-of-the-century London fashion, French visual arts, a Japanese production of Salomé, and Alla Nazimo- 
va's notorious Hollywood adaptation of the play, culminating (or climaxing, as one is sorely tempted to put it) in Joyce's Molly Bloom's equally notorious “demonic lust” (p. 281). These examples explain the emergence of a "women's sexual turn," from London to Tokyo, that, through subversive representations of prolonged female adolescence and a corset-free body, liberated female desire and disconnected it from its ostensibly natural characteristics.

John-Paul Riquelme’s “Oscar Wilde’s Anadoodlegram: A Genetic, Performative Reading of An Ideal Husband" moves away from cultural studies and interdisciplinarity amply exhibited by Gugullu's essay. Its intricate argument hinges on a close reading of Wilde's revisions of An Ideal Husband, including even his doodles on some of the drafts. Riquelme argues that all the revisions "support the centrality and the value of the performative in both the published version and the antecedent process that brought it into being through an interplay of signifiers and figures" (p. 287). Characterizing Wilde as an Irish (proto)modernist again, the critic suggests that this "interplay" prefigures the formal experimentation of James Joyce and Samuel Beckett.

In a sense, Felicia J.Ruff, in “Transgressive Props; or Oscar Wilde’s E(a)rnest Signifier," combines the materialist and textual approaches taken, respectively, by Gugullu and Riquelme. Wilde, Ruff argues, had a lifelong interest in home décor, as well as in stage props, and, as a result, his and George Alexander's 1895 production of The Importance of Being Earnest at the St. James Theater was not merely trend-setting in terms of the material culture of the time but also full of sexually subversive visual puns, including the famous cigarette cases. Returning briefly to the familiar Wilde-as-a-gay-martyr theme, Ruff recalls that, at the height of the AIDS epidemic, pink triangle pins, distributed by such LGBT organizations as Act Up and Queer Nation, were eerily similar to Wilde's cigarette cases in terms of their subversive capacity to speak volumes through silence.

Ending with a chapter on "afterlives" is a familiar feature of monographs and edited collections focusing on Wilde, and this collection is no exception. The stand-alone Chapter Thirteen, Ellen Crowell's "Christopher Millard's Mysterious Book: Oscar Wilde, Baron Corvo, and the Unwritten Quest," essentially gives voice to the silence of Ruff's cigarette cases and pink pins, by suggesting that Wilde has haunted the queer imagination long after his death. Crowell focuses on The Quest for Corvo: An Experiment in Biography (1934) by A. J. Symons and argues that this complexly layered modernist biography is a veiled biography of Wilde that Symons had longed to write and never had. Moreover, returning to the archival foundations of the volume, the critic concludes that "the intricacies surrounding the artist's [Wilde's] archival afterlives” led Symons to adopting, for his book, "a revelatory form through which modern subjectivity might be articulated” (p. 362). 
Since the book ends with Wilde's queer afterlives, I will permit myself to queer its conventional chronology and conclude by discussing the "Introduction," although, queerly, the discussion will veer back into heterosexuality. In his opening chapter, Joseph Bristow not only summarizes the arguments of the chapters and enumerates the many rewards awaiting a Wilde scholar at the Clark Library, but also dwells on the life and afterlife of Wilde's wife, Constance. He references Franny Moyle's biography of Constance Wilde, which I will discuss in the final section of this essay, and reveals a fascinating find: Wilde's four-act play which he started in 1894 and, in 1898, following the untimely death of his wife, decided to call Constance. The play portrays tensions in a late-Victorian marriage, bravely addressing the position of women, infidelity, and illegitimate pregnancy. Though attempts were made to produce the play after Wilde's death (Frank Harris even put on his own version, Mr. and Mrs. Davenport), it remains largely unknown. Calling attention to both puts Constance Wilde in a well-deserved spotlight and illuminates the variety and sophistication of Wilde's social, artistic, and sexual interests and causes.

Unlike Wilde Discoveries, which appeals to an audience of advanced students and scholars, Oscar Wilde in Context, edited by Kerry Powell and Peter Raby, is addressed to the beginner students and non-academic readers of Wilde, though the contributions, written by leading specialists, are useful to academic researchers as well. The essays are both thorough summaries of established knowledge and sources of innovative interpretations. The collection is also nicely interdisciplinary, drawing on the expertise of literary and theatre critics, historians, art historians, and creative writers to illuminate the many faces and facets of its subject's work and life.

The volume begins with an extensive chronology of Wilde's life and work, and, in a nod to a non-specialized audiences, with "An Appreciation: Oscar Wilde: The Art of the Somdomite," by the British playwright Mark Ravenhill, who, at the end of an exploration of Wilde intertwined with a personal history, concludes, "Today I feel content to accept that Wilde fits no single narrative" (p. 3). And indeed, the collection itself positions Wilde in a number of sociohistorical, cultural, and artistic contexts. Overall, the volume continues the "second-wave" trend of emphasizing Wilde's Irishness, relationship to the print culture, politics, and the women's movement, ending, almost inevitably with an array of essays on "afterlives." Gender and sexuality do get their due in Oscar Wilde in Context, though, as in Joseph Bristow's collection, their presence is not quite central.

The first section, "Placing Wilde," is both a nod to the current "place criticism" and a helpful guide to Wilde's most fundamental physical locations: Sean Ryder writes about the writer's parents, Lady Jane and Sir William Wilde, 
and their intellectual influence; Jerusha McCormack notes Wilde's cultural belonging to birthplace in "Wilde's Dublin; Dublin's Wilde." Moving along chronologically, the section introduces us to Wilde's formative intellectual experiences at Oxford through Philip E. Smith's "Oxford, Hellenism, Male Friendship." The concluding three sections take the readers on a journey to America (in Leon Litvack's "An Aesthete in America"); to "Wilde's London," as described by the historian of sexuality Matt Cook; and, to illustrate the current comparativeliterature trend in Wilde studies, to Paris, in "Wilde and Paris" by John Stokes.

The comparatist approach is central, as well, to the second section, "Aesthetic and Critical Contexts." The essays link Wilde's work to a multitude of national and international artistic and cultural context. Joseph Bristow hones in on the current interest in Wilde the classicist (further discussed in Iain Ross's Oscar Wilde and Ancient Greece, reviewed below) and explores the Ancient Greek antecedents of Wilde's "poetic traditions." Marcus Waithe, Richard Dellamora, and Susan Owens put Wilde's work in the context of visual arts, discussing, respectively, William Morris, Wilde's contemporary British arts, and Aubrey Beardsley's notorious illustrations of Salomé.

Jean Paul Riquelme, Peter Raby, and Ellis Hanson provide an extensive overview of Wilde the aesthete. While Riquelme discusses Wilde's perennial suspension between the teachings of John Ruskin and Walter Pater, Raby explores the "poisonous" decadent art of The Picture of Dorian Gray, and Hanson dwells on the beautiful surfaces of symbolism and discusses Wilde the stylist.

Wilde's contexts include not only his friends and teachers but also his rivals. Michèle Mendelssohn, the author of Henry James, Oscar Wilde and Aesthetic Culture, a definitive monograph on the subject, locates her discussion of aestheticism in the complex relationship between Oscar Wilde and Henry James. Anthony Roche links Wilde to another rival, Bernard Shaw, in "Bernard Shaw and 'Hibernian Drama." Kerry Powell continues the consideration of Wilde the playwright and his innovations in "Rewriting Farce." In a welcome reversal of the previous section's cultural and temporal chronology, this one culminates, rather than begins, with Wilde's Irishness. In his essay, Jarlath Killeen, the author of The Fairy Tales of Oscar Wilde, emphasizes the debt these tales own to the oral tradition in general, and the Irish oral tradition in particular.

The third section, "Cultural and Historical Contexts: Ideas, Iterations, Innovations," succeeds, as its subtitle states, in delineating the crucial contexts in which to understand Wilde, as well as in considering new context and in adding research to existing ones. Merlin Holland, Wilde's grandson, begins the section with a detailed overview of Wilde's trials, seeking to establish facts and to eliminate possible misconceptions. Harry Cocks concludes the section with "Wilde and the Law," an essay that establishes the extent to which the Wilde 
trials were typical (more than we may have expected), or atypical, for the legal and moral climate created by the 1885 Criminal Law Amendment. Between the two chapters dealing with the trials are essays that expose us to a multitude of other backgrounds and contexts.

Leading scholars of Victorian gender, James Eli Adams and Margaret D. Stetz, provide their analyses of dandyism and Wilde's complicated but significant relationship with the New Woman, respectively. Related to Margaret D. Stetz's "Oscar Wilde and the New Woman" is Barbara Caine's section on "Feminism" that notes Wilde's familiarity with the concerns and goals of the feminist movement of the day and his support of these concerns, particularly through the critique of sexual purity and moral Puritanism. Religion and, specifically, Christ, appear prominently in Wilde's essay "The Soul of Man under Socialism," and it is no wonder that Jacqueline Guy's "Oscar Wilde and Socialism" and Jan-Melissa Schramm's "Wilde and Christ” appear in one section and discuss Wilde's unconventional relationship with politics and religion. David Clifford's "Wilde and Evolution" offsets the topic of religion and provides a welcome introduction on the under-explored topic of Wilde's relationship with the work of Darwin, Huxley, and Lamarck, with which, like any educated Victorian, he was familiar, as well as preoccupied. Mark W. Turner's "Journalism" covers Wilde's contribution to print culture and periodicals, a topic of growing importance.

Print culture, editing, and textual criticism constitute a significant portion of the volume's last section, “Reception and Afterlives.” In the 1990s, during the first wave of the Wilde revival, a similar section in an edited collection would likely have focused on Wilde's importance as a role model and cultural icon for the LGBT movement, from Stonewall to Act Up. Oscar Wilde in Contexts concludes quite differently. Ian Small's essay focuses on "The Portrait of Mr. W. H.” (and on “Lord Arthur Savile's Crime”) but intertwines the stories' subversive sexuality with their textual history, specifically the availability of more than one version of the text. Similarly, in "Wilde and Performativity," Lynn Voskuil approaches the ostensibly familiar subject not by drawing on queer theory, but, rather, by exploring the specifically Victorian notions of persona-making and sincerity, especially as they appeared in the late-nineteenth-century press.

Some essays in the section, such as Joseph Donohue's "Reception and Performance History of The Importance of Being Earnest”; Steven Price's "A Short History of Salomé”; and Oliver S. Buckton's "Wilde Life: Oscar on Film” cover more familiar ground, while others introduce new or unjustly neglected perspectives. Sos Eltis discusses the afterlives of the society plays that often receive less attention than Earnest. Richard Cave's "Wilde and Stage Design: Some Deductions, Appraisals and Selected Instances” contributes further to the expanding 
body of scholarship on Wilde and material culture, while Russell Jackson's "Wilde and His Editors" is a fascinating account of the availability and usefulness of various editions of Wilde's work and their effect on Wilde scholarship. Oscar Wilde in Context is an indispensable book: the high quality of editing ensures that very short essays invariably pack significant informative and critical punch.

\section{Shifting Chronologies, or Wilde Modernism}

Both Powell and Raby's and Bristow's edited collections draw attention to changes in our perception of Oscar Wilde in terms of literary chronologies; selected chapters in each volume explicitly or implicitly characterize Wilde as one of the first modernists. Both the ongoing theoretical discussion of temporality and the reconsideration of the canon in college curricula have had an impact on the location of Wilde on the chronological continuum of Anglophone literature. To put the change in rough-and-ready terms: while, in the past, a chapter on Wilde concluded monographs on Victorian literature, today it starts monographs on modernism. A case in point is Andrew Goldstone's Fictions of Autonomy: Modernism from Wilde to de Man. It is still unusual but, ultimately, productive to think about Wilde as starting the twentieth century, rather than ending the nineteenth, especially since Wilde's attention to form is proto-modernist, even proto-Formalist. Wilde defies us to rethink Norton-Anthology-style straightforward chronologies.

Current modernist scholarship, Goldstone suggests, tends to reject T. S. Eliot's ostensibly outdated formalist notion of the complete autonomy of a work of art, or, for that matter, Wilde's call to "reveal the art and conceal the artist." Goldstone's own astute and innovative study "argues that the ideas of aesthetic autonomy are...central to both the history of modernist literature and the discipline of literary studies" (p. 1). The book defines autonomy and argues that modernism does, as well, in a variety of ways: class, art, geography, and university curricula all play a part in this definition.

In addition to reading closely selected modernist and, as the author terms them, "protomodernist" texts, Fictions of Autonomy deploys a variety of theoretical approaches, from Bourdieu to German philosophy, to define autonomy; it also shows awareness and ability to enter into a productive dialogue with recent research on modernism. The title - and indeed the subsequent discussion smartly plays on the word "fiction" to emphasize both the artistic means by which modernist autonomy is constructed and its very ideological constructed-ness, or fictitiousness. 
Wilde appears in the first chapter, "Autonomy from Labor: In Service to Art for Art's Sake from Wilde to Proust." The chapter begins by asserting that "Oscar Wilde stands near the origin" of the modernist preoccupation with the autonomy of art which "leads to the elevation of aesthetic form above all things" (p. 24). Its goal is to combine the usual discussion of form that is central to early modernism with a shot-in-the arm of social relevance (which, as stereotypical thinking goes, the work of the likes of Wilde, James, and Proust consciously eschews, concentrating, instead, on art for art's sake). Goldstone argues that "Wilde's depiction of "Phipps the butler [in An Ideal Husband] is a prototypical fiction of autonomy, self-reflexively representing the primacy of aesthetic form even as it underscores form's social embeddedness” (p. 25). Phipps, the insubordinate subordinate, "makes us aware of the truths of class intruding into the magic circle of art..." and "comes to stand for the unpleasant material and human social reality - the unwanted content - that he is meant to exclude" (p. 28). The chapter addresses the relationship between the unsettling materiality of labor (especially servants' labor) in Proust, Huysmans, and James, but it also then draws attention to The Picture of Dorian Gray, specifically to the hitherto barely noticed Victor, Dorian Gray's valet. Such an approach is particularly useful, since the few analyses of the novel that do take class into account focus primarily on the Vane siblings.

With regard to Dorian Gray, Goldstone writes,

The servant still represents the dominance of form for Dorian, but that dominance is no longer a reassuring sign of the varied pleasures of beautiful things and sparkling wit; instead, the mirror, in showing Dorian not his own lovely reflection but the potentially deceptive surface of his servant's face, reveals to him that the mask of form signifies a world of terrifying, unknown content. (p. 36)

Other servants in the novel - particularly “the nameless servant of Lord Henry's Aunt Agatha" (p. 38) - also, the chapter contends, force us to face the complex interaction between "reality" and its representation, between form and content.

Wilde, as Goldstone notes, is not a stranger to class-related debates, citing, of course, "The Soul of Man under Socialism." Evidence mounts when we pay attention to Wilde's post-Reading-Gaol prison-reform activism, not mentioned in the book. The project of challenging the supposed rarified elitism of art for art's sake that the chapter undertakes is both useful and skillfully done. However, the author describes the materiality, or content, represented by the servants, as "terrifying" and "unknown," and unknown, for the most part, it remains. One wishes for a more rigorous definition of what materiality and content constitute for the purposes of this line of argument, as well as for more textual, or contextual, evidence of their unbearable presence. Without such specificity, to 
quote Lady Bracknell, “[t]he line is immaterial” (The Importance of Being Earnest, Act I) or, worse, forced. Somewhat rigid, as well, is the "masters are form, and servants are content" dichotomy permeating the chapter - especially the Wilde section - and reinforcing the very class hierarchies that the reading here seeks to critique.

The remaining chapters discuss autonomy in Eliot and Adorno in relation to "the late style"; autonomy, nation, otherness, and exile in James Joyce and Djuna Barnes; and the autonomy of the text in Paul de Man's writings. In all of these insightful discussions, Wilde is somehow present without being mentioned. His capacious definition of autonomy probably would have included all of these. The book concludes with "The Epilogue: Autonomy Now," which focuses on the impact of the modernist notions on autonomy on today's college curriculum and literary criticism. While "giv[ing] pause to would-be debunkers of all claims to aesthetic autonomy," Goldstone also hopes to "convince[] would-be celebrants of the religion of art...to pursue their devotion to art into all the complex reality of art's worldly relations" (p. 194). In part, it is this redefinition of modernism and its central tenets that allows us, in the first place, to count Wilde amongst its early practitioners.

\section{Wilde and His Others: Postcolonial and Ethnic-Studies Approaches}

While the 1990s scholarship tried hard to avoid describing Wilde in strictly identitarian terms (even as, ironically, it made him a poster child of identity), current scholarship pays greater attention to Wilde's Irishness and shows the relevance of ethnic-studies approaches to Wilde's work. Two recent titles, Éibhear Walshe's Oscar's Shadow: Wilde, Homosexuality, and Modern Ireland and S. I. Salamensky's The Modern Art of Influence and the Spectacle of Oscar Wilde, invite us to consider Wilde's relevance, respectively, to Irish and Jewish Studies.

Walshe's well-researched study has two related goals. First, it shows Wilde's sexuality in the context of evolving views on gay and lesbian sexuality in Ireland, from the late nineteenth century to the present day. The study's second goal is to demonstrate that "Wilde in Irish culture was perceived not so much as Wilde the unspeakable but much more as Wilde the dissident Irishman” (p. xiii). The use of adjectives here illustrates a larger shift in Wilde scholarship. While earlier scholarship placed emphasis on "the unspeakable" (in the sense of sexually dissident and unidentifiable), Walshe wants us to view Wilde as still dissident but identifiably, even unmistakably, Irish. Throughout the book, Walshe argues persuasively that the perception of Wilde in his native land had changed in the course of the 
century along with Ireland's political and social landscape, both in terms of the growing acceptance of queer sexuality and in terms of the country's sense of itself as an independent political entity.

In the first chapter, Walshe discusses a variety of responses (and non-responses) of the Irish press to the Wilde trials and argues that, in Ireland, Wilde's name was not subjected to the kind of condemnation it did in Britain and the United States. Chapters Two and Three, in convincing detail, combining historical and literary research with a strong grasp of LGBTQ studies, describe the relationship between the persistence of Wilde's name, which, the author contends, could not be erased, with Ireland's struggle for independence and its establishment of autonomy and statehood in the first half of the twentieth century. Wilde's personal and artistic tribulations proved uniquely resonant with his country's fight for self-determination.

Chapter Four, perhaps the book's most fascinating, concerns the role of the actor and dramatist Micheál mac Líammóir (born Alfred Willmore in London). In mid-twentieth century, mac Líammóir, an openly gay artist, partnered with the director Hilton Edwards, and, like Wilde, a master of self-reinvention, became responsible for creating and maintaining a publicly acceptable image of Wilde. Walshe argues that this image "could be accommodated and presented in mainstream social discourse in Ireland, permitting a contemporary reclaiming of Wilde the gay Irishman" (p. 56).

The next two chapters of the monograph deftly intertwine Irish Studies, LGBTQ Studies, and literary, theatre, and film analysis in order to show that

Ireland experienced radical economic, legal and social change during the last half of the twentieth century and into the twenty-first century and so the name of Oscar Wilde was refashioned to suggest or even invent a more inclusive sense of Irishness. (p. 69)

As he does throughout the book, here, Walshe suggests a complex interplay of the need for a well-defined identity ("a gay Irishman") and the necessity of "invention" in the process of nation-building. Thus, Wilde is both pinned down and constantly refashioned in the course of Ireland's development.

For instance, in contemporary Irish literature, Wilde is reinvented as a "new symbol of...post-imperialism" (p. 89). No matter the role it assumes in the public and artistic discourse of contemporary Ireland, the figure of Wilde has paved the way toward greater openness of discourse on sexuality. Walshe refuses, however, to paint a rosy picture. The book concludes with a discussion of the Dublin City Council's refusal to rename Merrion Square Park as Oscar Wilde Gardens. Despite the malleability and adaptability of his image throughout the twentieth century, the figure of Wilde retains a kernel of resistance. Though visible and identifiable, he still fights authority. 
While Walshe's book joins a small but growing and influential club, ${ }^{3}$ Salamensky's monograph, a significant part of which puts Wilde in the context of Jewish Studies, breaks completely new ground. The reasons for this long-time omission are multiple, according to Salamensky, as well as deep-seated and jarring: unwillingness to accuse Wilde, already martyred by the prejudiced, of having prejudices of his own; Jewish critics' hidden shame and resulting reticence, as well as the unpopularity of this branch of identity studies in Britain (most scholars of Wilde are British literature scholars). As someone who has recently argued Wilde's worldliness and open-mindedness toward the character of Isaacs in The Picture of Dorian Gray, I find Salamensky's reading of Wilde unsettling, in the way new scholarship worth its salt should be, but, ultimately, well-researched and convincing. ${ }^{4}$

Salamensky analyzes a variety of influential Wildean performances, both in life and in art, both during his lifetime and posthumously. Wilde and the "Jewish question" is not her sole focus. The first chapter delves into Wilde's public performance on the American tour, as well as into the contentious relationship between Wilde and Henry James (consisting mostly of the latter's psychic projections, fantasmatic rivalries, and literary interpretations). The third chapter explores performances of Wilde's most famous plays, An Ideal Husband and The Importance of Being Earnest, and argues that, despite many possible political and social interpretations of these plays (for instance, Salamensky critically engages with Kerry Powell's and Sos Eltis's respective analyses of Wilde's society plays vis-à-vis turn-of-the-century feminisms), the plays, above all, are linguistically dazzling and demonstrate "how vital and complex the staging of language can be" (p. 112). The chapter concludes with a favorable response to a 2011 New York Roundabout Theater production of Earnest and the accompanying website and film that, according to Salamensky, stress Wilde's continuing relevance.

The fourth chapter continues the theme of Wilde and modernity and reflects on today's perceptions of a variety of Wilde's performances (or performances of Wilde) on contemporary stage and screen. The chapter's concerns are wideranging, from the popularity of The Picture of Dorian Gray among today's nonacademic readers and its treatment of sexuality and desire, to the tragic brilliance of Wilde's trials performance, regrettably oversimplified, according to Salamens-

3 See Wilde the Irishman, a 1998 collection edited by Jerusha MacCormack, to which Walshe makes a reference, as well as Killeen's aforementioned monograph on Wilde's fairy tales.

4 See Helena Gurfinkel, “Queer, Cosmopolitan,” in The Cambridge History of Gay and Lesbian Literature, ed. E. L. McCallum and Mikko Tuhkanen. Cambridge, New York: Cambridge University Press, 2014. 402-418. 
ky, by Moisés Kaufman's play Gross Indecency: The Three Trials of Oscar Wilde, “a plodding, dutiful docudrama” (p. 152). Like Petra Dierkes-Thrun, whose book, Salome's Modernity: Oscar Wilde and The Aesthetics of Transgression, was also published in 2011, Salamensky dismisses earnestly identitarian and conscientiously historiographic cinematic and theatrical treatments of Wilde, such as Gross Indecency, or the Irish film A Man of No Importance, and lauds the more playful and complex works, such as Todd Haynes's Velvet Goldmine (and even I'm not There, unrelated to Wilde) and Tom Stoppard's play The Invention of Love. In the same spirit, in the conclusion, she writes, "I am not certain what the book says” (p. 153).

I am, however, quite certain what the book's most innovative and original contribution is. When describing Wilde's U. S. tour, Salamensky notes that the American press stressed the otherness of Wilde's looks, particularly his facial features. She also observes that Gabriel Nash, a character in Henry James's novel The Tragic Muse that is based on Oscar Wilde, is both Svengali-like and identified with the Jewish actress Miriam Roof, thus redoubling his Otherness. The by now familiar conflation of queerness and Jewishness sets up the expectation that Salamensky will portray Wilde, a good friend of Ada Leverson and Reginald Turner, as sympathetic to the other Other under siege in turn-of-the-century Europe. Such an approach would align her narrative with Walshe's: shared oppression leads to solidarity, pride, and empowerment.

The author's careful research leads her to a different and much more troubling conclusion. In fact, Salamensky wonders why, during the Dreyfus affair, Wilde, a recently imprisoned gay man and exiled Irishman, does not express such solidarity with the French Jewish officer. She argues that, both in his work and in his letters and conversations, Wilde harbors fairly conventional Victorian antiSemitic views, unlike, for instance, George Eliot, whose Daniel Deronda, the protagonist of the eponymous novel, is the philosemitic antithesis to Sibyl Vane's vulgar manager Isaacs. Salamensky contends further that the Jewish character in The Florentine Tragedy, Wilde's little-known play, is reminiscent of Shylock, and that, in An Ideal Husband, Baron Arnheim, Mrs. Cheveley's former lover, is a corrupt and corrupting Jew, who is more akin to Anthony Trollope's immoral crypto-Jewish, Shylock-like money-grabbers, Ferdinand Lopez in The Prime Minister and Augustus Melmotte in The Way We Live Now, than to the seductive aesthete, Lord Henry Wotton.

Salamensky's analysis of Salomé seeks to “...investigate...greatly overlooked...nineteenth-century constructs and complexes surrounding, respectively, 'the Jew' and 'the hysteric'” (p. 36). She deftly accounts for the play's antecedents and afterlives and explains clearly the linked fin-de-siècle views on Jewishness and hysteria. She adds that, as his one-act symbolist play demonstrates, Wilde's 
prejudice limits itself to male Jews, who are treated cursorily and dismissively. The princess Salomé makes identification possible because she instantiates "the Jewess's putatively active, rather than receptive, sexuality: in the erotic terms of the period, a masculinity that would safely mask a paean to obsession with the beauty of a young man" (p. 61).

While a more nuanced analysis of Isaacs, and especially of Lord Henry's defense of him, would have benefited Salamensky's discussion, as would have a consideration of a brief but interesting reference to Jews and the ghetto in Wilde's fairy tale "The Happy Prince," her research is path-breaking and opens up important new possibilities.

\section{Wilde the Scholar and Philosopher}

In the Arnoldian duality of Hebraism and Hellenism, Wilde is famously in the side of Hellenism. In the last two decades, Wilde's classical scholarship has been addressed by some studies, most notably, Linda Dowling's seminal Hellenism and Homosexuality in Victorian Oxford. However, most references to classical antiquity in relation to Wilde's life and art have almost inevitably been in service of sexuality. With good reason, Wilde's knowledge of Greek philosophy and literature has been shown as instrumental to encoding subversively, or legitimizing openly, relationships between men as a protest against Victorian heteronormativity and rigid models of masculinity. Wilde does so, for instance, by structuring his critical dialogues in Intentions and the intellectual seduction in The Picture of Dorian Gray as Greek homosocial/homoerotic pedagogy.

Iain Ross's exemplarily well-researched Oscar Wilde and Ancient Greece offers an exploration of the writer's relationship to Ancient Greece virtually divorced from the matters of gender and sexuality. Instead, following the contemporary critical trend of crediting Wilde with more than the status of an unrepentant dandy, Ross focuses his attention on Wilde's profound engagement, via Greek philosophy and art, as well as the scholars who had taught him Greek philosophy and art, with the matters of imagination, form, criticism, heredity, and the transmission of knowledge. In a useful nod to textual criticism and the history of publishing, Ross also writes that the goal of his study is "to examine how Wilde's Hellenism was complicated by the particularities of the institutions, texts and editions through which he encountered ancient Greek literature and material culture" (p. 5).

The first chapter, "Paideia," as the title suggests, engages with the young Wilde's gradual immersion in Greek scholarship, starting with his interest in Greek and Celtic archeology, encouraged by his father, the polymath and physi- 
cian Sir William Wilde, and echoing in interesting ways Walshe's and Castle's discussions of Wilde's Irishness. The chapter also considers Wilde's successful study of the classics at the Portora School and Trinity College in Dublin (mentored by J. P. Mahaffy, who remained a life-long influence) and at Oxford. Ross interweaves a discussion of abstract matters of archeology, authority, truth, and artifact with a concrete account of Wilde's student days and travels to Greece in much the same way as Wilde's classical scholarship itself mingles philosophy with an exploration of material objects.

The second chapter, "Poiesis," confronts the conflict between the scientific, positivist discoveries of Victorian archeology and the romanticized version of Greece that these discoveries had worked to erode. Having grounded Wilde's position in the debate in J. A. Symmonds's and Walter Pater's writings on Greek mythopoetics, Ross concludes that

\footnotetext{
Wilde's strong identification with the culture of the fourth century BC, the late classical period, 'the age of style' that he considered a suitable analogue for his own era, made nostalgia for an authentic origin, of the kind implied by Pater's interest in Archaic Greece, redundant. Instead, he sought a synthesis of his nature and his culture, symbolized by his myth of the self-conscious individual originator of all myths: an ancestor Wilde would contemplate without any sense of loss. (p. 67)
}

In a tone and diction that, surprisingly (for a study that is not at all, on the face of it, post-structuralist), are almost Derridian, Ross, like Goldstone, points to Wilde's proto-modernist commitment to form and individualism, but unlike Goldstone's, Ross's reading is not, in this chapter at least, critical of these tendencies.

The high point of the second chapter is Ross's brilliant analysis of the poetic encounter between Wilde's "Charmides" and "The Sphinx" and Keats's "Endymion," "Lamia," and "Ode on a Grecian Urn." Linking the close reading of the poems to the questions of nineteenth-century archeology, science, style, and authenticity underlying the chapter, Ross concludes:

At the beginning of the century Keats's ode responded to the enthusiastic amateurism of archeology's inception; by the end of the century the discipline had been professionalised and specialised, casting over the previously free realm of antiquity a net of chronological and topographical overdetermination. In writing 'Charmides,' Wilde had attempted to tailor his poetry to the exigencies of Keats's era, producing an uncomfortable hybrid. In writing The Sphinx, he took Keats's ode and made it his own; he brought it up to date. (p. 80)

Like poetic imitation, translation is a dialogue between texts. Appropriately, the chapter concludes with a discussion of both Wilde's translations from Greek and his writings on translation. Continuing the theme of archeology and its influence on the Victorian perceptions of Greece, Ross contends that Wilde's 
translations, in seeking to smooth the roughness of their model, embody conflicting tendencies to both neo-classicism and romanticism, suggesting that his attraction to the 'new,' archeologically inflected Greece of the 1870 s was retarded by his allegiance to older, more normative ideals (p. 88).

Not only did Wilde translate from Greek, but he also reviewed others' translations, most notably Lord Carnavon's and William Morris's. Especially with respect to "naturalizing” Greek for the nineteenth-century English reader, Wilde goes back and forth between accepting and rejecting Matthew Arnold's precepts laid out in On Translating Homer. Ultimately, Wilde posits that "the task of the translator" (to use Walter Benjamin's words) is to adapt Greek to English sufficiently to avoid its exclusion from the school curriculum and to preserve its pleasures, as Ross puts it beautifully, "for future Keatses" (p. 96).

The third chapter, "Archailogia," builds on this conclusion by introducing the themes of the democratization of Greek through pedagogy and the materialization of classical education. One wishes, too, that through greater accessibility and gracefulness of style and critical apparatus (possibly an unfair expectation of such a strictly academic volume), Ross's own writing had done more to democratize and popularize its valuable new insights into Wilde's career.

The chapter begins by outlining the growing accessibility of traditional education to the working classes and women, as well as Wilde's own participation in the process through his public lectures and editorship. Ross discusses Wilde's approach to the material objects, such as the oft-mentioned Tanagra statuettes, as well as his commitment to reproducing classical antiquity on stage. Ultimately, however, Ross argues, after 1886, Wilde the maturing artist abandons the claim to accuracy laid by the archeological approach to antiquity and prioritizes imagination and form:

Archeological reconstruction was of value inasmuch as it could demonstrate how the Greek spirit had manifested itself in the material conditions under which it had first arisen...; but having once determined what it had been, the archaeologist had to give way to the architect, the artist, the writer... (p. 122)

Not surprisingly, then, the chapter concludes with a discussion of "The Decay of Lying," perhaps Wilde's most crucial manifesto of what it means to be an artist. Wilde's commitment to form, Ross argues, echoes an essay called "The Old School of Classics and the New" by his former Trinity tutor Tyrell. In his important discussion of style, Wilde both acknowledges and innovates upon his Greek antecedents.

The final chapter, "Philologia," is the book's most detailed discussion of Greek influences on Wilde's writing, stressing consistently his ability both to deploy and to reinvent his Greek sources. The first half of the chapter delves into 
Wilde's break with J. P. Mahaffy's classicism and interest in T. H. Green's writings on ethics (and their influence on "The Soul of Man under Socialism"), as well as into Wilde's continuous dialogue with Plato and Aristotle on the matters on ethics and aesthetics.

In a fascinating discussion of The Picture of Dorian Gray, for the first time, to my knowledge, Ross takes up the Greek connotations of the protagonist's name and connects his dandyism to a form of ancient militarism. The section on The Importance of Being Earnest argues that Wilde's most famous play echoes Menander's representative New Comedy Ion and is thus "as independent of the nineteenth-century conditions of its production as the New Comedy was of the survival of its originating fourth-century texts” (p. 182).

The concluding section, perhaps the most predictable one in an otherwise genuinely original study, tackles Wilde's move away from Hellenism and toward Christianity in works, such as De Profundis. This move could never be complete, however: "No matter how Wilde tried, he could never escape that region of his imagination called Greece” (p. 193).

\section{Constance}

Traditionally, Wilde's connection to Greece is linked to homoeroticism, veiled or open, but the second-wave revival has been paying attention to Wilde the bisexual husband and father. In his contribution to Wilde Discoveries, Joseph Bristow unveils fascinating research on Wilde's unfinished play, Constance, a risqué melodrama of infidelity and illegitimate pregnancy that reveals his remarkable (though at times contested) sympathy toward the position of women in the Victorian marriage. In her essay in Oscar Wilde in Context, Margaret D. Stetz stresses a powerful, albeit complex, cultural and political connection between Wilde and the New Woman. Both scholars make a reference to Wilde's wife, Constance, who had not hitherto received much attention as more than a constant wife and mother whose life was tragically ruptured by her husband's trials and imprisonment.

Constance Wilde, born Constance Lloyd, in London in 1858, is the subject of Franny Moyle's lively Constance: The Tragic and Scandalous Life of Mrs. Oscar Wilde. Moyle's is not the first biography of Constance Wilde. Anne Clark Amor's Mrs. Oscar Wilde: A Woman of Some Importance was published in 1983. A sufficiently long time had passed, however, to renew the public's interest in Oscar Wilde's wife, and, overall, Moyle's effort is a success. The biography, clearly aimed at a general reader who has some familiarity with Wilde's life and work, rather than at a strictly scholarly audience, is written in an accessible but still 
intellectually rigorous manner. Moyle has thoroughly investigated her subject's life and work, and her obvious warm sympathy toward Constance (not unusual in a biographer) does not, nonetheless, render this book a simplistic condemnation of her husband.

The title itself is interesting: the use of "Mrs. Oscar Wilde," is, I think, tinged with irony, showing that there is more to Constance than her domestic duties, while the words "tragic" and "scandalous," frequently applied to Wilde himself, seek to re-appropriate these qualities and to give Constance's life depth and significance. Moyle deserves credit for introducing a psychological sketch of Constance influenced by an unhappy childhood and maternal neglect (though such an approach is a bit deterministic and not entirely original). She also grants sufficient complexity to the Wilde marriage, pointing out that it served both to stifle and to stimulate Constance's creative and intellectual pursuits. Indeed, Moyle's biggest contribution to the reintroduction of Constance Wilde to the public is the well-researched foray into her intellectual, artistic, and political activities, such as journalism, theatre, and participation in the Rational Dress Society, the Philosophical Society, and the Women's Committee of the International Arbitration and Peace Association. Joseph Bristow has discovered a play in which the wife named Constance is at once constant and rebellious; ultimately, she takes a step toward the subversion of the Victorian marital hierarchy. Similarly, Moyle's Constance is a woman who, despite the physical and moral trials befalling her, stubbornly retains a unique selfhood that is worth remembering and studying further.

As I have noted, Moyle's biography is a popular book, aiming to interest a non-academic audience in Constance Wilde's intellectual contributions and personal plight. Since the first-wave Wilde revival was scholarly, as well as popular, my hope is that the second-wave revival will produce popular cinematic and literary re-imaginings of Wilde and his circle. Future scholarly monographs and collections should explore further the postcolonial and comparatist potentialities of Wilde's work, emphasizing his simultaneous ability both to inspire movements of national liberation and to undo the idea of a nation-state and national literature. Likewise, Wilde's contributions to, and adumbrations of, twentieth-century philosophy and literary theory constitute a topic rife with possibilities. Iain Ross's book sets a fine example of researching Wilde's relationship with classical and nineteenth-century philosophical and political thought.

Audiences beyond the academy would welcome a "definitive" biopic that would replace and update the brave and timely 1997 Wilde, as well as new biographies of the members of the fascinating Wilde family, from his mother, the feminist firebrand Speranza, his sons, Cyril and Vyvyan, to his niece Dolly, a 
queer icon in her own right. ${ }^{5}$ I do not believe that such family portraits would diminish Wilde's statue as a tireless fighter against the hypocrisy and rigidity of traditional values (after all, there is nothing traditional about any of the Wildes). Instead, they would reflect the multitudes of identities and statements against identity that his figure (barely) contains.

\section{Works Cited}

Bristow, Joseph. Effeminate England: Homoerotic Writing after 1885. New York: Columbia UP, 1995. Print.

id. (ed.). Wilde Discoveries: Traditions, Histories, Archives. Berkeley, Los Angeles, CA: The U of California P, 2013. Print.

Butler, Judith. Gender Trouble: Feminism and the Subversion of Identity. London, New York: Routledge, 1990. Print.

Clark Amor, Anne. Mrs. Oscar Wilde: A Woman of Some Importance. London: Sidgwick and Jackson, 1983. Print.

Cohen, Ed. Talk on the Wilde Side: Towards a Genealogy of a Discourse on Male Sexualities. London, New York: Routledge, 1992. Print.

Craft, Christopher. Another Kind of Love: Male Homosexual Desire in English Discourse, 1850-1920. Berkeley, Los Angeles, CA: The U of Press, 1994. Print.

Dellamora, Richard. Masculine Desire: The Sexual Politics of Victorian Aestheticism. Durham, NC: The U of North Carolina P, 1990. Print.

Dierkes-Thrun, Petra. Salome's Modernity: Oscar Wilde and the Aesthetics of Transgression. Ann Arbor, MI: The U of Michigan P, 2011. Print.

Dollimore, Jonathan. Sexual Dissidence: Augustine to Wilde, Freud to Foucault. Oxford, New York: Oxford UP, 1991. Print.

Dowling, Linda. Hellenism and Homosexuality in Victorian Oxford. Ithaca, NY: Cornell UP, 1994. Print.

Gagnier, Regenia. Idylls of the Marketplace: Oscar Wilde and the Victorian Public. Stanford, CA: Stanford UP, 1986. Print.

Goldstone, Andrew. Fictions of Autonomy: Modernism from Wilde to de Man. Oxford, New York: Oxford UP, 2013. Print.

Gurfinkel, Helena. "Queer, Cosmopolitan.” The Cambridge History of Gay and Lesbian

Literature. Eds. E. L. McCallum and Mikko Tuhkanen. Cambridge, New York: Cambridge UP, 2014. 402-418. Print.

Kaufman, Moisés. Gross Indecency: The Three Trials of Oscar Wilde. New York: Vintage, 1998. Print.

Killeen, Jarlath. The Fairy Tales of Oscar Wilde. Aldershot: Ashgate, 2013. Print.

5 Biographies of Jane and Dolly Wilde do exist, though they have not received much attention. Joan Schenkar published Truly Wilde: The Unsettling Story of Dolly Wilde, Oscar's Unusual Niece, in 2001, while Karen Tipper's A Critical Biography of Lady Jane Wilde, 1821?-1896: Irish Revolutionist, Humanist, Scholar and Poet, came out in 2002. 
MacCormack, Jarusha (ed.). Wilde the Irishman. New Haven, CT: Yale UP, 1998. Print. A Man of No Importance. Dir. Suri Krishnamma. Perf. Albert Finney, Brenda Fricker, Michael Gambon. BBC Films, 1994. Film.

Mendelssohn, Michèle. Henry James, Oscar Wilde and Aesthetic Culture. Edinburgh: Edinburgh UP, 2007. Print.

Moyle, Franny. Constance: The Tragic and Scandalous Life of Mrs. Oscar Wilde. New York: Pegasus Books, 2011, 2012. Print.

Powell, Kerry; Raby, Peter (eds.). Oscar Wilde in Context. Cambridge, New York: Cambridge UP, 2014. Print.

Ross, lain. Oscar Wilde and Ancient Greece. Cambridge, New York: Cambridge UP, 2011, 2012. Print.

Salamensky, S. I. The Modern Art of Influence and the Spectacle of Oscar Wilde. New York: Palgrave Macmillan, 2011. Print.

Schenkar, Joan. Truly Wilde: The Unsettling Story of Dolly Wilde, Oscar's Unusual Niece. Amherst, MA: De Capo Press, 2001. Print.

Sedgwick, Eve Kosofsky. “Tales of the Avunculate: The Importance of Being Earnest." Tendencies. Durham, London: Duke UP, 1993. 52-72. Print.

Sinfield, Alan. The Wilde Century: Effeminacy, Oscar Wilde, and the Queer Moment. New York: Columbia UP, 1994. Print.

Tipper, Karen Sasha Anthony. A Critical Biography of Lady Jane Wilde, 1821?-1896: Irish Revolutionist, Humanist, Scholar and Poet. Lewiston, NY: Edwin Mellen Press, 2002. Print.

Trollope, Anthony. The Prime Minister. Ed. David Skilton. New York: Penguin, 1996. Print.

id. The Way We Live Now. Ed. Karen Odden. New York: Barnes and Noble Classics, 2005. Print.

Walshe, Éibhear. Oscar's Shadow: Wilde, Homosexuality, and Modern Ireland. Cork: Cork UP, 2011. Print.

Wilde. Dir. Brian Gilbert. Perf. Stephen Fry, Jude Law, Vanessa Redgrave. BBC, Capitol Films, Dove International, 1997. Film.

Wilde, Oscar. The Importance of Being Earnest. The Importance of Being Earnest and Other Plays: Lady Windermere's Fan; Salomé; A Woman of No Importance; An Ideal Husband; The Importance of Being Earnest. Ed. Peter Raby. Oxford, New York: Oxford UP. 247-307. Print. 